\title{
PENGARUH LAYANAN INFORMASI TERHADAP PENYESUAIAN DIRI SISWA SMP NEGERI 18 BATAM
}

\author{
Musripah dan Junierissa Marpaung \\ Dosen Tetap Prodi Bimbingan Konseling Universitas Riau Kepulauan Batam
}

\begin{abstract}
Abstrak
Penyesuaian diri siswa yang rendah dapat menghambat perkembangan di usia remaja karena penyesuaian diri merupakan salah satu tugas perkembangan remaja. Layanan informasi dapat digunakan untuk meningkatkan penyesuaian diri siswa. Penelitian ini bertujuan untuk mengungkapkan efektifitas layanan informasi dalam meningkatkan penyesuaian diri siswa di SMPN 18 Batam.

Penelitian ini menggunakan metode kuantitatif dengan jenis penelitian pre-eksperimentaldesain. Dalam penelitian ini hanya ada satu kelas eksperimen yang mendapat layanan informasi dan selanjutnya dianalisis dengan paired sample statistics dengan bantuan. SPSS version 21. Penelitian ini dilakukan dengan 5 kali layanan. b) penyesuaian diri siswa sesudah diberi layanan informasi. c) pengaruh layanan informasi terhadap penyesuaian diri siswa.

Berdasarkan analisis data ditemukan layanan informasi memberikan kontribusi yang sangat besar terhadap penyesuaian diri siswa. Berdasarkan temuan di atas dapat disimpulkan bahwa sebelum diberikan layanan informasi siswa dalam kondisi penyesuaian diri rendah dengan kategori sangat rendah $77 \%$, kategori rendah $11 \%$, kategori sedang 9\%, kategori tinggi 3\%. Setelah diberikan layanan informasi terdapat peningkatan penyesuaian diri pada siswa kategori sangat tinggi 3\%, kategori tinggi $14 \%$, kategori sedang $66 \%$, kategori rendah $17 \%$. Dari hasil penelitian yang telah dilakukan terdapat pengaruh layanan informasi terhadap penyesuaian diri siswa yang diberikan peneliti sebanyak 5 kali layanan. Perubahan yang terjadi pada kelas eksperimen ini sangat tinggi dengan banyaknya perubahan. Hal ini terbukti tidak ada lagi siswa yang memiliki penyesuaian diri rendah.
\end{abstract}

Kata kunci: Layanan Informasi, Penyesuaian Diri

\section{PENDAHULUAN}

\section{Latar Belakang Masalah}

Semua makhluk hidup secara alami dibekali kemampuan untuk menolong dirinya sendiri dengan cara menyesuaikan diri dengan keadaan lingkungan, agar dapat bertahan hidup. Namun pada kenyataannya, banyak individu yang gagal dalam penyesuaian diri karena individu belum tentu tahu apa yang dinamakan dengan proses penyesuaian diri, selain itu individu tidak memiliki konsep penyesuaian diri dan tidak melakukan penyesuaian diri dengan baik. Hal ini sangat berpengaruh terhadap kehidupan individu dalam menghadapi segala tantangan dan perubahan-perubahan yang akan terjadi nanti.

Selain itu, penyesuaian diri merupakan salah satu persyaratan penting bagi terciptanya kesehatan jiwa atau mental individu. Banyak individu yang menderita dan tidak mampu mencapai kebahagiaan dalam hidupnya. Karena ketidakmampuan menyesuaikan diri, baik dengan kehidupan keluarga, sekolah, pekerjaan dan dalam masyarakat pada umumnya. Tidak jarang pula ditemui bahwa 
orang-orang mengalami stress dan depresi disebabkan oleh kegagalan mereka untuk melakukan penyesuaian diri dengan kondisi penuh tekanan. Sesuai dengan pengertiannya, maka tingkah laku manusia dapat dipandang sebagai reaksi terhadap berbagai tuntutan dan tekanan lingkungan tempat individu hidup.

Sedangkan menurut Scheneider (dalam Zainal Aqib,2012:13) mengartikan penyesuaian diri sebagai suatu proses respon individu baik yang bersifat behavioral maupun mental dalam upaya mengatasi kebutuhan-kebutuhan dari dalam diri, ketegangan emosional, frustrasi dan konflik, serta memelihara keseimbangan antara pemenuhan kebutuhan tersebut dengan tuntutan (norma).

Menurut Havighurst (dalam Sobur, 2010: 139), anak belajar peranan jenis kelamin, kontak dengan teman sebaya, belajar sikap terhadap kelompok dan lembaga-lembaga. Selain itu siswa kelas VIII SMP sedang memasuki lingkungan yang berbeda dengan masa sebelumnya. Hal ini berpotensi menyebabkan masalah dalam dirinya termasuk masalah penyesuaian diri yang rendah, antara lain masalah penyesuaian diri dengan guru, teman, mata pelajaran dan lingkungan. Akibatnya anak tidak mau sekolah, tidak mau belajar, suka membolos, berani melawan guru dan pada akhirnya prestasi belajar menurun. Untuk itu penyesuaian diri yang rendah harus ditingkatkan agar tidak mengganggu anak dalam mencapai perkembangan yang optimal di sekolah.

Terkait dengan permasalahan ini lembaga pendidikan wajib ikut berperan dalam memberikan pelayanan secara ekstra, contohnya berperan membantu siswa untuk mencegah atau menghindarkan diri dari berbagai permasalahan yang menghambat perkembangan diri, serta membantu siswa memelihara dan menumbuh-kembangkan berbagai potensi dan kondisi positif yang dimilikinya secara optimal. Terkait dengan adanya layanan informasi diharapkan dapat mempermudah guru BK dalam menigkatkan penyesuaian diri siswa baik di sekolah maupun lingkungan tempat tinggalnya. Selanjutnya untuk mencegah hal-hal yang tidak diinginkan, diperlukan usaha pencegahan sejak dini dengan memberikan layanan bimbingan dan konseling khususnya layanan informasi.

Sedangkan menurut Achmad Juntika, (2006: 53) mengatakan bahwa layanan informasi bertujuan untuk membekali siswa dengan berbagai pengetahuan dan pemahaman tentang berbagai hal yang berguna untuk mengenal diri, merencanakan, dan mengembangkan pola kehidupan sebagai pelajar, anggota keluarga, dan masyarakat. Pemahaman yang diperoleh melalui layanan informasi digunakan sebagai bahan acuan dalam meningkatkan kegiatan dan prestasi belajar, mengembangkan cita-cita, menyelenggarakan kehiupan sehari-hari dan mengambil keputusan. Fungsi utama layanan informasi adalah pemahaman dan pencegahan.

Adapun permasalahan-permasalahan yang peneliti temukan berdasarkan hasil wawancara dengan guru di SMP Negeri 18 Batam antara lain adalah, secara keseluruhan setiap kelas terdapat siswa yang penyesuaian dirinya kurang. Fenomena tersebut didukung oleh wawancara sebagai peneliti dengan beberapa siswa kelas VIII SMPN 18 Batam yang mendapatkan hasil seperti, (1) bahwa beberapa siswa kurang begitu mengenal dekat teman sekelasnya dan bahkan ada yang tidak saling menyukai antar sesama teman sekelas. Kemudian peneliti juga melakukan wawancara dengan siswa lain tentang guru 
yang baru, dan hasil wawancara diketahui bahwa (2) siswa tersebut kurang begitu menyukai guru yang baru tersebut karena cara mengajar yang kurang dapat diterima oleh mereka.

Fenomena tersebut juga ditunjang oleh data yang diperoleh dalam bentuk media cetak yaitu hasil need asessment yang berupa sosiometri, berdasarkan data tersebut dijelaskan bahwa permasalahan secara umum yang dialami siswa di sekolah adalah masalah pribadi dan sosial. Sesuai dengan isu yang merebak diatas mengenai rendahnya tingkat penyesuaian diri siswa di sekolah, apabila hal tersebut tidak segera ditangani kebutuhan siswa dalam bidang pribadi, belajar, sosial dan karir akan terhambat dan mengakibatkan kurang optimalnya hasil belajar, dikarenakan lingkungan sekolah juga sangat mempengaruhi proses belajar mengajar.

Apabila seorang siswa mampu menyesuaikan diri dengan lingkungan sekolah, maka siswa tersebut kemungkinan besar mendapatkan hasil belajar yang memuaskan, dan juga sebaliknya. Melihat fenomena yang terjadi pada siswa kelas VIII SMP N 18 Batam dapat menyebabkan proses kegiatan belajar mengajar terhambat dan prestasi belajar menurun. Guna meningkatkan penyesuaian diri siswa di sekolah tersebut dapat digunakan beberapa cara yang efektif, salah satunya adalah layanan informasi

Dari permasalahan yang dihadapi siswa sebagaimana disebutkan di atas, diharapkan dengan layanan Informasi akan dapat memberikan solusi (problem solving) bagi siswa untuk dapat melakukan penyesuaian dirinya pada lingkungan budaya yang ada di sekolahnya, sehingga akan tercipta suasana kegiatan belajar mengajar yang kondusif yang pada akhirnya tidak tertutup kemungkinan tujuan pendidikan akan tercapai.

Selanjutnya, untuk melakukan kajian ilmiah ini, peneliti mengadakan observasi yang memfokuskan diri pada kelas VIII SMPN 18 Batam, sebagai tempat pelaksanaan penelitian dengan alasan bahwa di sekolah ini latar belakang siswanya berbeda-beda, seperti latar belakang pekerjaan orang tua yang kebanyakan nelayan dan petani, lingkungan yang tidak mendukung seperti adanya tempat hiburan, serta rendahnya perhatian orang tua terhadap pendidikan anak-anaknya. Dari permasalahan yang berbeda inilah penyesuaian diri siswa-siswi di sekolah tersebut berbeda pula. Berpijak dari permasalahan di atas, peneliti tertarik untuk melakukan penelitian yang berjudul “Pengaruh Layanan Informasi terhadap Penyesuaian Diri Siswa SMPN 18 Batam”.

\section{RUMUSAN MASALAH}

Berdasarkan latar belakang di atas, maka rumusan masalah dari penelitian ini adalah:

1. Bagaimana penyesuaian diri siswa sebelum diberikan layanan informasi di SMP Negeri 18 Batam?

2. Bagaimana penyesuaian diri siswa sesudah diberikan layanan informasi di SMP Negeri 18 Batam?

3. Apakah ada pengaruh layanan informasi terhadap penyesuaian diri siswa di sekolah SMP Negeri 18 Batam? 


\section{TUJUAN PENELITIAN}

Sesuai dengan rumusan permasalah di atas, maka tujuan utama dari penelitian ini adalah:

1. Untuk mengetahui penyesuaian diri siswa di SMP Negeri 18 Batam sebelum diberikan layanan informasi.

2. Untuk mengetahui penyesuaian diri siswa di SMP Negeri 18 Batam setelah diberikan layanan informasi.

3. Untuk mengetahui pengaruh penyesuaian diri siswa di SMP Negeri 18 Batam sebelum dan sesudah diberikan layanan informasi.

\section{METODE}

\section{Metode Penelitian}

Jenis penelitian yang digunakan dalam penelitian ini yaitu Pre-experimental Design, karena desain ini belum merupakan eksperimen sungguh-sungguh. Menurut (Sugiyono, 2013: 74-75) penelitian Pre-experimental Design dibagi menjadi tiga, dari tiga desain penelitian tersebut peneliti menggunakan jenis One-Group Pretest-Posttest Design untuk melakukan penelitian. Dengan demikian hasil perlakuan dapat diketahui lebih akurat, karna dapat membandingkan dengan keadaan sebelum diberikan perlakuan. Desain penelitian dapat digambarkan sebagai berikut.

\begin{tabular}{|ccc|}
\hline (Pre-test $)$ & Perlakuan & $($ Post - test $)$ \\
\hline $\mathrm{O} 1$ & $\mathrm{X}$ & $\mathrm{O} 2$ \\
\hline
\end{tabular}

Gambar 1. Desain penelitian one group pretest-posttest design

Keterangan:

O1 = Perlakuan awal (pre-test), untuk mengukur penyesuaian diri siswa pada sampel sebelum diberikan layanan informasi.

$\mathrm{X}=$ Pengaruh antara layanan informasi terhadap penyesuaian diri siswa

$\mathrm{O} 2$ = Perlakuan akhir (post-test), untuk mengukur pengaruh penyesuaian diri pada sampel setelah diberikan layanan informasi.

\section{Pengumpulan Data}

Metode pengumpulan data adalah suatu metode yang digunakan untuk mengumpulkan bahanbahan sebagai data. Data primer dalam penelitian ini dikumpulkan dengan: (a). Angket Penyesuaian Diri dan (b). Dokumentasi berupa materi untuk pemberian Layanan Informasi Siswa. 


\section{ANALISIS DATA}

Menurut Sugiyono, (2013:147) mengatakan teknik analisis data dalam penelitian kuantitatif menggunakan statistik, jadi analisis data merupakan kegiatan setelah data dari seluruh responden atau sumber lain terkumpul. Analisis data digunakan untuk menguji hipotesis dan menjawab rumusan masalah yang diajukan, karena menggunakan data interval yaitu data yang jaraknya sama tetapi tidak mempunyai nilai nol mutlak (absolut), maka sebelum melakukan pengujian harus dipenuhi uji prasyarat terlebih dahulu sebagaimana dijelaskan berikut ini. Dalam penelitiaan ini metode analisis data mengunakan t-test. Metode analisis data digunakan bertujuan untuk menjawab penelitian dan menguji hipotesis yang diajukan, apakah diterima atau ditolak.

Dalam penelitian ini pengujian hipotesis yang digunakan peneliti adalah uji satu pihak (One Tail Test). Uji satu pihak ada dua macam salah satu yang digunakan adalah Uji pihak kanan, artinya uji pihak kanan digunakan apabila hipotesis nol (Ho) berbunyi lebih kecil atau sama dengan $(\leq)$ dan hipotesis alternatifnya (Ha) berbunyi “ lebih besar $(\geq)$ ”. Sebelum peneliti melakukan analisis data terlebih dahulu melakukan uji prasyarat yaitu:

\section{Uji Normalitas}

Uji normalitas adalah uji untuk mengukur apakah data kita memiliki distribusi normal sehingga dapat dipakai didalam statistik parametrik, jika data tidak berdistribusi normal dapat dipakai statistik non parametrik. Uji normalitas adalah melakukan perbandingan antara data yang kita miliki dengan data berdistribusi normal yang memiliki mean dan standar deviasi yang sama denganstandar. Peneliti mengunakan one- sample Kolmogorov-Smirnov test.

\section{HASIL}

Hasil kategori ini berdasarkan rumus menurut Saifuddin Azwar (2004:108)

Tabel 1. Penghitungan Distribusi Penyesuaian Diri Siswa.

\begin{tabular}{|l|l|l|}
\hline Perhitungan & Rentangan Skor & Kategori \\
\hline $135+1,5.22,5<\mathrm{X}$ & $167,75<\mathrm{X}$ & Sangat Tinggi \\
\hline $135+0,5.22,5<\mathrm{X} \leq(135+1,5.22,5)$ & $146,25<\mathrm{X} \leq 168,75$ & Tinggi \\
\hline $135-0,5.22,5<\mathrm{X} \leq 135+0,5.22,5$ & $123,75<\mathrm{X} \leq 146,25$ & Sedang \\
\hline$(135-1,5.22,5)<\mathrm{X} \leq(135-0,5.22,5)$ & $101,25<\mathrm{X} \leq 123,75$ & Rendah \\
\hline $\mathrm{X} \leq(135-1,5.22,5)$ & $\mathrm{X} \leq 101,25$ & Sangat Rendah \\
\hline
\end{tabular}


Dari data di atas dapat disimpulkan kategori penyesuaian diri seperti tabel di bawah ini:

Tabel 2. Distribusi Penyesuaian Diri Siswa

\begin{tabular}{|l|l|l|}
\hline No & Interval & Kategori \\
\hline 1 & $\mathrm{X} \leq 101,25$ & Sangat Rendah \\
\hline 2 & $101,25<\mathrm{X} \leq 123,75$ & Rendah \\
\hline 3 & $123,75<\mathrm{X} \leq 146,25$ & Sedang \\
\hline 4 & $146,25<\mathrm{X} \leq 168,75$ & Tinggi \\
\hline 5 & $167,75<\mathrm{X}$ & Sangat Tinggi \\
\hline
\end{tabular}

\section{Deskripsi Data Pre-Test Penyesuaian Diri Kelas Eksperimen}

Sesuai dengan tujuan pretest yaitu untuk mengetahui kondisi penyesuaian diri siswa sebelum diberikan perlakuan. Adapun data hasil Pretest yang dilakukan dapat disajikan pada tabel di bawah ini :

Tabel 3. Skor Pretest Kelas Eksperimen

\begin{tabular}{|c|c|c|c|}
\hline No & Inisial & Skor & Kategori \\
\hline 1. & $\mathrm{AF}$ & 100 & Sangat Rendah \\
\hline 2. & $\mathrm{AL}$ & 80 & Sangat Rendah \\
\hline 3. & AM & 97 & Sangat Rendah \\
\hline 4. & $\mathrm{ADK}$ & 85 & Sangat Rendah \\
\hline 5. & AM & 126 & Sedang \\
\hline 6. & DCR & 89 & Sangat Rendah \\
\hline 7. & $\mathrm{DS}$ & 100 & Sangat Rendah \\
\hline 8. & $\mathrm{DM}$ & 97 & Sangat Rendah \\
\hline 9. & ES & 109 & Rendah \\
\hline 10. & EA & 120 & Rendah \\
\hline 11. & GM & 53 & Sangat Rendah \\
\hline 12. & IW & 96 & Sangat Rendah \\
\hline
\end{tabular}




\begin{tabular}{|c|c|c|c|}
\hline 13. & $\mathrm{IO}$ & 90 & Sangat Rendah \\
\hline 14. & LJM & 60 & Sangat Rendah \\
\hline 15. & LS & 75 & Sangat Rendah \\
\hline 16. & $\mathrm{MDK}$ & 51 & Sangat Rendah \\
\hline 17. & MF & 101 & Sangat Rendah \\
\hline 18. & MAF & 91 & Sangat Rendah \\
\hline 19. & $\mathrm{NSN}$ & 67 & Sangat Rendah \\
\hline 20. & NAP & 60 & Sangat Rendah \\
\hline 21. & NMA & 92 & Sangat Rendah \\
\hline 22. & $\mathrm{RP}$ & 99 & Sangat Rendah \\
\hline 23. & RA & 124 & Sedang \\
\hline 24. & SNR & 104 & Rendah \\
\hline 25. & SNJ & 92 & Sangat Rendah \\
\hline 26. & $\mathrm{SF}$ & 61 & Sangat Rendah \\
\hline 27. & SS & 96 & Sangat Rendah \\
\hline 28. & TAK & 92 & Sangat Rendah \\
\hline 29. & WS & 88 & Sangat Rendah \\
\hline 30. & $\mathrm{ZN}$ & 90 & Sangat Rendah \\
\hline 31. & ARN & 46 & Sangat Rendah \\
\hline 32. & $\mathrm{RS}$ & 59 & Sangat Rendah \\
\hline 33. & $\mathrm{KS}$ & 91 & Sangat Rendah \\
\hline 34. & $\mathrm{RG}$ & 158 & Tinggi \\
\hline 35. & $\mathrm{HH}$ & 143 & Sedang \\
\hline
\end{tabular}

Setelah diadakan pretest pada kelompok eksperimen terdapat 27 siswa dengan kategori sangat rendah, 4 siswa dengan kategori penyesuaian diri rendah, 3 dengan kategori penyesuaian diri sedang, 1 orang dengan kategori penyesuaian diri tinggi. Setelah melakukan pretest peneliti memberikan layanan informasi sebanyak 5 kali layanan. Setelah layanan selesai peneliti mengadakan posttest kepada kelas eksperimen. Adapun hasil persentase dapat disajikan dalam tabel di bawah ini:

Tabel 4. Hasil Frekuensi Pretest Kelas Eksperimen 


\begin{tabular}{|l|l|l|l|}
\hline No & Kategori & Frekuensi & Persentase (\%) \\
\hline 1 & Sangat Rendah & 27 & $77 \%$ \\
\hline 2 & Rendah & 4 & $11 \%$ \\
\hline 3 & Sedang & 3 & $9 \%$ \\
\hline 4 & Tinggi & 1 & $3 \%$ \\
\hline 5 & Sangat Tinggi & 0 & $0 \%$ \\
\hline & Total & 35 & $100 \%$ \\
\hline
\end{tabular}

Dari tabel di atas pada hasil pretest terdapat kategori penyesuaian diri siswa sangat rendah sebanyak $77 \%$ (27 orang siswa), kategori rendah 11\% (4 orang siswa), kategori sedang sebanyak 9\% (3 orang siswa), kategori tinggi 3\% (1 orang siswa), Hal ini menyatakan bahwa hasil pretest menyatakan penyesuaian diri siswa sangat rendah. Adapun hasilnya skor pretest dapat kita lihat pada grafik di bawah ini:

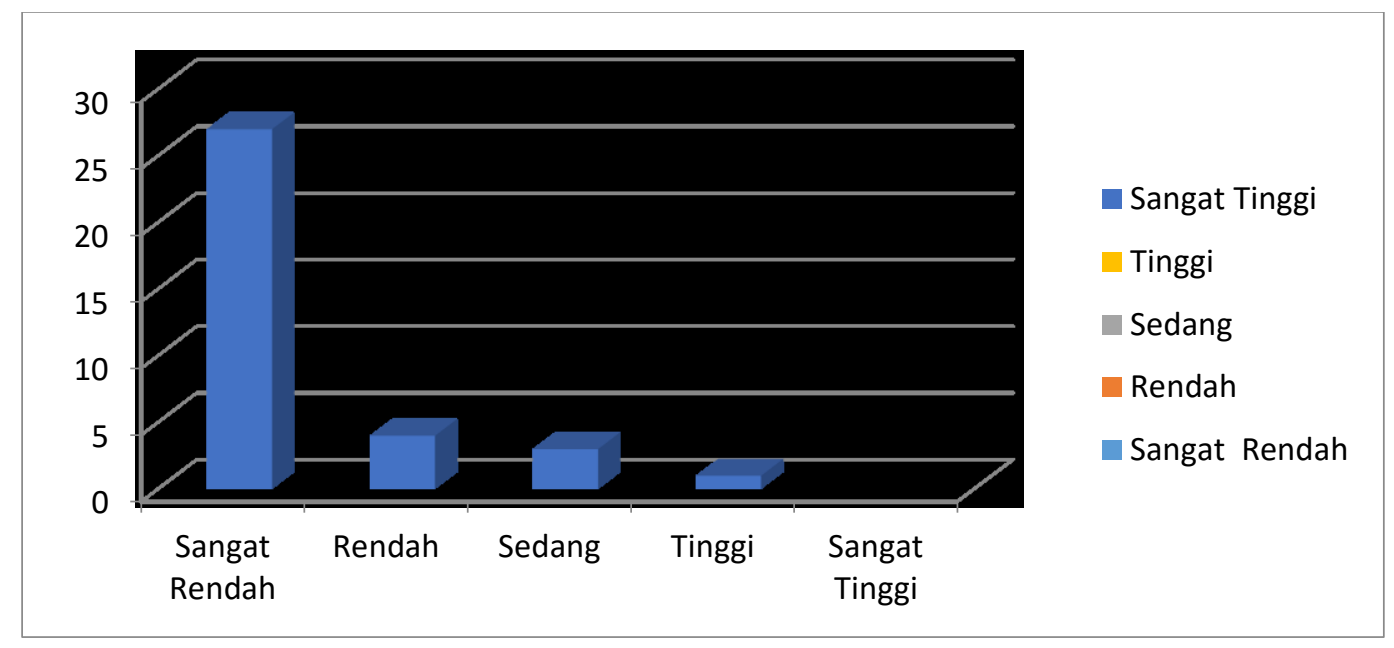

Gambar 2. Grafik Skor Pretest Kelompok Eksperimen

\section{Deskripsi Data Post-Test Penyesuaian Diri Kelas Eksperimen}

Setelah memberikan perlakuan peneliti melakukan posttest dengan tujuan untuk mengetahui penyesuaian diri siswa pada kelas eksperimen setelah diberi layanan informasi. Adapun hasil posttest tersebut disajikan dalam bentuk tabel di bawah ini:

Tabel 4.5. Skor Posttest Kelompok Eksperimen

\begin{tabular}{|l|c|c|c|}
\hline \multicolumn{1}{|c|}{ No } & Inisial & Skor & Kategori \\
\hline $\mathbf{1 .}$ & AF & 111 & Rendah \\
\hline $\mathbf{2 .}$ & AL & 118 & Rendah \\
\hline 3. & AM & 134 & Sedang \\
\hline
\end{tabular}




\begin{tabular}{|c|c|c|c|}
\hline 4. & $\mathrm{ADK}$ & 147 & Tinggi \\
\hline 5. & AM & 142 & Sedang \\
\hline 6. & DCR & 139 & Sedang \\
\hline 7. & $\mathrm{DS}$ & 131 & Sedang \\
\hline 8. & $\mathrm{DM}$ & 128 & Sedang \\
\hline 9. & $\mathrm{ES}$ & 145 & Sedang \\
\hline 10. & EA & 142 & Sedang \\
\hline 11. & GM & 140 & Sedang \\
\hline 12. & IW & 146 & Sedang \\
\hline 13. & $\mathrm{IO}$ & 151 & Tinggi \\
\hline 14. & LJM & 154 & Tinggi \\
\hline 15. & $\mathrm{LS}$ & 134 & Sedang \\
\hline 16. & MDK & 140 & Sedang \\
\hline 17. & $\mathrm{MF}$ & 114 & Rendah \\
\hline 18. & MAF & 124 & Sedang \\
\hline 19. & NSN & 117 & Rendah \\
\hline 20. & NAP & 129 & Sedang \\
\hline 21. & NMA & 164 & Tinggi \\
\hline 22. & $\mathrm{RP}$ & 144 & Sedang \\
\hline 23. & RA & 132 & Sedang \\
\hline 24. & SNR & 117 & Rendah \\
\hline 25. & SNJ & 173 & Sangat Tinggi \\
\hline 26. & SF & 166 & Tinggi \\
\hline 27. & SS & 138 & Sedang \\
\hline 28. & TAK & 138 & Sedang \\
\hline 29. & WS & 134 & Sedang \\
\hline 30. & $\mathrm{ZN}$ & 125 & Sedang \\
\hline
\end{tabular}




\begin{tabular}{|l|c|c|c|}
\hline 31. & ARN & 133 & Sedang \\
\hline 32. & RS & 122 & Rendah \\
\hline 33. & KS & 138 & Sedang \\
\hline 34. & RG & 127 & Sedang \\
\hline 35. & HH & 128 & Sedang \\
\hline
\end{tabular}

Dari tabel hasil posttest dapat kita simpulkan bahwa ada 1 siswa yang memiliki penyesuaian diri sangat tinggi, 5 siswa memiliki penyesuaian diri tinggi, 23 siswa memiliki penyesuaian diri sedang dan ada 6 siswa yang memiliki penyesuaian diri rendah. Adapun hasil data persentase yang didapatkan dapat kita jelaskan pada tabel di bawah ini:

\section{Tabel 6. Hasil Frekuensi Posttest Penyesuaian Diri Kelas Eksperimen}

\begin{tabular}{|l|l|l|l|}
\hline No & Kategori & Frekuensi & Persentase (\%) \\
\hline 1 & Sangat rendah & 0 & $0 \%$ \\
\hline 2 & Rendah & 6 & $17 \%$ \\
\hline 3 & Sedang & 23 & $66 \%$ \\
\hline 4 & Tinggi & 5 & $14 \%$ \\
\hline 5 & Sangat tinggi & 1 & $3 \%$ \\
\hline & Total & 35 & $100 \%$ \\
\hline
\end{tabular}

Dari tabel di atas dapat kita ketahui hasil posttest pada kelas eksperimen bahwa banyak terdapat peningkatan setelah dibarikan layanan informasi dimana kategori sangat rendah $0 \%$, kategori rendah 17\% ( 6 orang siswa) kategori sedang menjadi 66\% (23 orang siswa), kategori tinggi $14 \%$ ( 5 orang siswa), kategori sangat tinggi 3\% (1 orang siswa). Untuk lebih jelasnya dapat kita lihat pada gerafik dibawah ini:

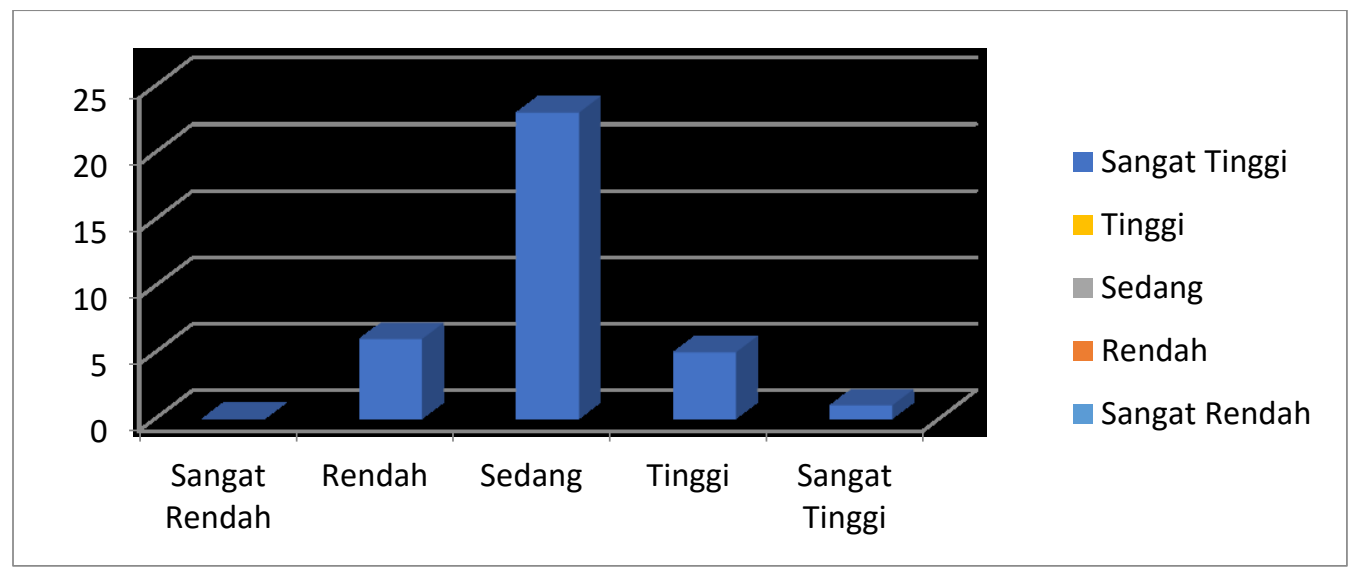

Gambar 3. Grafik Posttest Penyesuaian Diri Kelas Eksperimen

\section{Perbandingan Pre-Test dan Post-Test Kelas Eksperimen}


Setelah mendapatkan perlakuan siswa pada kelas eksperimen diberikan posttest. Yang bertujuan membandingkan hasil antara sebelum diberi layanan dan sesudah diberi layanan. Adapun hasil pretest dan posttest dapat disajikan pada tabel di bawah ini:

Tabel 7. Hasil Pretest dan Posttest Kelompok Eksperimen

\begin{tabular}{|c|c|c|c|c|c|}
\hline \multirow{2}{*}{ No } & & \multicolumn{2}{|r|}{ Pretest } & \multicolumn{2}{|c|}{ Posttest } \\
\hline & Inisial & Skor & Kategori & Skor & Kategori \\
\hline 1. & $\mathrm{AF}$ & 100 & Sangat Rendah & 111 & Rendah \\
\hline 2. & $\mathrm{AL}$ & 80 & Sangat Rendah & 118 & Rendah \\
\hline 3. & $\mathrm{AM}$ & 97 & Sangat Rendah & 134 & Sedang \\
\hline 4. & ADK & 85 & Sangat Rendah & 147 & Tinggi \\
\hline 5. & $\mathrm{AM}$ & 126 & Sedang & 142 & Sedang \\
\hline 6. & $\overline{\mathrm{DCR}}$ & 89 & Sangat Rendah & 139 & Sedang \\
\hline 7. & DS & 100 & Sangat Rendah & 131 & Sedang \\
\hline 8. & DM & 97 & Rangat Rendah & 128 & Sedang \\
\hline 9. & ES & 109 & Rendah & 145 & Sedang \\
\hline 10. & EA & 120 & Rendah & 142 & Sedang \\
\hline 11. & GM & 53 & Sangat Rendah & 140 & Sedang \\
\hline 12. & IW & 96 & Sangat Rendah & 146 & Sedang \\
\hline 13. & IO & 90 & Sangat Rendah & 151 & Tinggi \\
\hline 14. & LJM & 60 & Sangat Rendah & 154 & Tinggi \\
\hline 15. & LS & 75 & Sangat Rendah & 134 & Sedang \\
\hline 16. & MDK & 51 & Sangat Rendah & 140 & Sedang \\
\hline 17. & $\mathrm{MF}$ & 101 & Sangat Rendah & 114 & Rendah \\
\hline 18. & MAF & 91 & Sangat Rendah & 124 & Sedang \\
\hline 19. & NSN & 67 & Sangat Rendah & 117 & Rendah \\
\hline 20. & NAP & 60 & Sangat Rendah & 129 & Sedang \\
\hline 21. & NMA & 92 & Sangat Rendah & 164 & Tinggi \\
\hline
\end{tabular}




\begin{tabular}{|c|c|c|c|c|c|}
\hline $\mathbf{2 2 .}$ & RP & 99 & Sangat Rendah & 144 & Sedang \\
\hline $\mathbf{2 3 .}$ & RA & 124 & Sedang & 132 & Sedang \\
\hline $\mathbf{2 4 .}$ & SNR & 104 & Rendah & 117 & Rendah \\
\hline $\mathbf{2 5 .}$ & SNJ & 92 & Sangat Rendah & 173 & Sangat Tinggi \\
\hline $\mathbf{2 6 .}$ & SF & 61 & Sangat Rendah & 166 & Tinggi \\
\hline $\mathbf{2 7 .}$ & SS & 96 & Sangat Rendah & 138 & Sedang \\
\hline $\mathbf{2 8 .}$ & TAK & 92 & Sangat Rendah & 138 & Sedang \\
\hline $\mathbf{2 9 .}$ & WS & 88 & Sangat Rendah & 134 & Sedang \\
\hline $\mathbf{3 0 .}$ & ZN & 90 & Sangat Rendah & 125 & Sedang \\
\hline $\mathbf{3 1 .}$ & ARN & 46 & Sangat Rendah & 133 & Sedang \\
\hline $\mathbf{3 2 .}$ & RS & 59 & Sangat Rendah & 122 & Rendah \\
\hline $\mathbf{3 3 .}$ & KS & 91 & Sangat Rendah & 138 & Sedang \\
\hline $\mathbf{3 4 .}$ & RG & 158 & Tinggi & 127 & Sedang \\
\hline $\mathbf{3 5 .}$ & HH & 143 & Sedang & 128 & Sedang \\
\hline $\mathbf{B e r d a s a n g}$ & & & & & \\
\hline
\end{tabular}

Berdasarkan tabel di atas maka dapat diketahui bahwa terdapat perbedaan yang signifikan antara hasil pretest dan postest. terdapat kenaikan skor penyesuaian diri siswa setelah dilakukan layanan informasi. Yang dapat kita perhatikan pada tabel diatas bahwa banyak siswa yang mengalami perubahan penyesuaian diri. terdapat 31 siswa yang mengalami perubahan penyesuaian diri dan hanya terdapat 4 siswa yang belum mengalami perubahan. Adapun data perbedaan pretest dan posttest dapat dilihat pada tabel di bawah in

Tabel 8. Distribusi Hasil Frekuensi Persentase Pretest dan Posttest Eksperimen

\begin{tabular}{|l|l|l|l|l|l|}
\hline No & \multicolumn{1}{|c|}{ Kategori } & \multicolumn{1}{|c|}{ Pretest } & Persentase & \multicolumn{1}{c|}{ Posttest } & Eksperimen \\
\hline 1 & Sangat Rendah & 27 & $77 \%$ & - & - \\
\hline 2 & Rendah & 4 & $11 \%$ & 6 & $17 \%$ \\
\hline 3 & Sedang & 3 & $9 \%$ & 23 & $66 \%$ \\
\hline 4 & Tinggi & 1 & $3 \%$ & 5 & $14 \%$ \\
\hline 5 & Sangat Tinggi & - & - & 1 & $3 \%$ \\
\hline
\end{tabular}




\begin{tabular}{|l|l|l|l|l|l|}
\hline & TOTAL & 35 & $100 \%$ & 35 & $100 \%$ \\
\hline
\end{tabular}

Dari data di atas dapat kita ambil kesimpulan bahwa kelompok eksperimen dengan layanan informasi mengalami peningkatan penyesuaian diri yang sangat signifikan. Sebelum mendapatkan layanan kategori siswa sangat rendah ada $77 \%$ dan menurun menjadi $0 \%$, kategori rendah dari $11 \%$ menjadi $17 \%$, kategori sedang $9 \%$ menjadi $66 \%$, kategori tinggi $3 \%$ menjadi $14 \%$, ketegori sangat tinggi dari $0 \%$ menjadi $3 \%$. Sehingga dapat disimpulkan setelah diadakan layanan siswa rata-rata dalam kategori penyesuaian diri sedang dan tinggi.

\section{Perbedaan Kategori Pretest dan Posttest pada Kelompok Eksperimen Pretest Eksperimen Posttest Eksperimen}

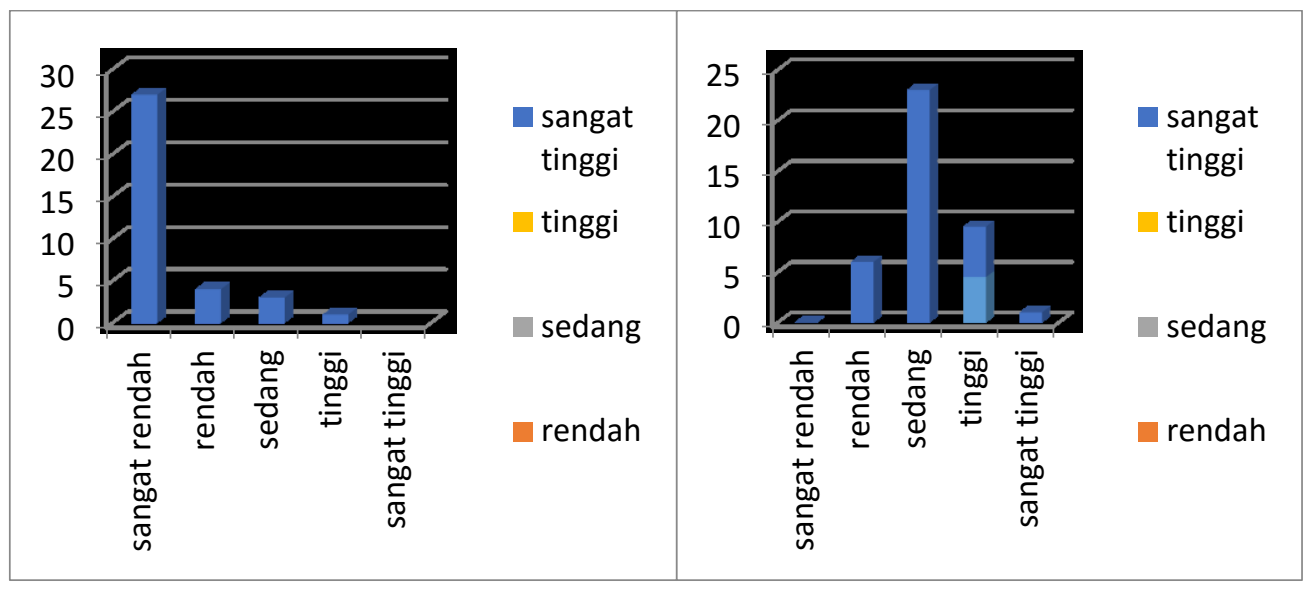

Gambar 4. Grafik Perbedaan pretest dan posttest kelompok eksperimen.

\section{Uji Prasyarat Analisis}

\section{Uji Normalitas}

Uji normalitas dilakukan dengan menggunakan SPSS statistics version 21 for windows. Pada ukuran atau taraf signifikan $\alpha=0,05$. jika $\geq 0,05$ maka sampel berasal dari populasi berdistribusi normal. Jika $<0,05$ maka sampel tidak berdistribusi normal (dalam Ghozali, 2011: 165). Adapun hasilnya adalah sebagai: 
Tabel 9. Hasil Uji Normalitas

One-Sample Kolmogorov-Smirnov Test

\begin{tabular}{|c|c|c|c|}
\hline & Pretest & Posttest \\
\hline \multicolumn{2}{|l|}{$\bar{N}$} & 35 & 35 \\
\hline Normal & Mean & 90.9143 & 136.1429 \\
\hline Parameters ${ }^{\mathrm{a}, \mathrm{b}}$ & Std. Deviation & 24.97690 & 14.37756 \\
\hline \multirow{3}{*}{$\begin{array}{l}\text { Most Extreme } \\
\text { Differences }\end{array}$} & Absolute & .143 & .085 \\
\hline & Positive & .143 & .085 \\
\hline & Negative & -.139 & -.059 \\
\hline \multicolumn{2}{|c|}{ Kolmogorov-Smirnov Z } & .847 & .501 \\
\hline \multicolumn{2}{|c|}{ Asymp. Sig. (2-tailed) } & .470 & .963 \\
\hline
\end{tabular}

a. Test distribution is Normal.

b. Calculated from data.

Untuk layanan pretest eksperimen tingkat sig 0.470 maka $\geq 0.05$ maka berdistribusi normal, layanan informasi posttest eksperimen 0.963 maka $\geq 0,05$ sehingga berdistribusi normal.

\section{Uji Hipotesis}

Uji hipotesis data hasil penelitian harus memenuhi kriteria bahwa data berdistribusi normal.Pengujian hipotesis dilakukan untuk melihat adanya pengaruh perlakuan terhadap kelas penelitian. Pengujian hipotesis dilakukan meggunakan uji t pada taraf signifikansi $\alpha=0,05$. Kriteria keputusan pengujian hipotesis:

1. Tolak Ho dan terima Ha, bila probabilitas signifikan $(\alpha \leq 0,05)$

2. Terima Ho dan Tolak Ha, bila probabilitas signifikan $(\alpha \geq 0,05)$

\section{a. Pengujian Rumusan Masalah Pertama}

Hipotesis pertama yang diajukan dalam penelitian ini adalah" Bagaimana penyesuaian diri siswa sebelum diberikan layanan informasi di SMP Negeri 18 Batam?”.

Berdasarkan skor yang diperoleh siswa sebelum diberi layanan siswa dalam kategori penyesuaian diri rata-rata sangat rendah. dengan data terdapat $77 \%$ siswa yang menempati kategori penyesuaian diri sangat rendah.

\section{b. Pengujian Rumusan Masalah Kedua}

Hipotesis kedua yang diajukan dalam penelitian ini adalah "Bagaimana penyesuian diri siswa sesudah diberikan layanan informasi di SMP Negeri 18 Batam ?”. 
Paired Samples Test

\begin{tabular}{|c|c|c|c|c|c|c|c|c|}
\hline & \multicolumn{5}{|c|}{ Paired Differences } & \multirow[t]{3}{*}{$T$} & \multirow[t]{3}{*}{ df } & \multirow{3}{*}{$\begin{array}{c}\text { Sig.(2 } \\
\text { tailed } \\
\text { ) }\end{array}$} \\
\hline & \multirow[t]{2}{*}{ Mean } & \multirow[t]{2}{*}{$\begin{array}{c}\text { Std. } \\
\text { Deviation }\end{array}$} & \multirow[t]{2}{*}{$\begin{array}{l}\text { Std. } \\
\text { Error } \\
\text { Mean }\end{array}$} & \multicolumn{2}{|c|}{$\begin{array}{l}\text { 95\% Confidence } \\
\text { Interval of the } \\
\text { Difference }\end{array}$} & & & \\
\hline & & & & Lower & Upper & & & \\
\hline $\begin{aligned} & \text { pretest } \\
\text { Pair } 1 & - \\
& \text { postest }\end{aligned}$ & -45.22857 & 30.37422 & 5.13418 & -55.66248 & -34.79466 & -8.809 & 34 & .000 \\
\hline
\end{tabular}

Setelah posttest dilakukan terdapat peningkatan penyesuaian diri siswa setelah diberi layanan informasi, hal ini sesuai data yang didapatkan tidak ada lagi siswa yang memiliki penyesuaian diri sangat rendah. Terdapat 17\% siswa dalam kategori rendah, 66\% dalam kategori sedang, dan penyesuaian diri tinggi terdapat $14 \%$. Bila disimpulkan seluruh kelas eksperimen terdapat peningkatan penyesuaian diri.

\section{c. Pengujian Rumusan Masalah Ketiga}

Hipotesis ketiga yang diajukan dalam penelitian ini ialah "apakah terdapat pengaruh layanan informasi terhadap penyesuaian diri siswa di SMP Negeri 18 Batam?"

Pengujian hipotesis ini dilakukan dengan tehnik analisis data mengunakan uji paired sample T-Test melalui SPSS statistics versi 21 for windows. Berdasarkan hal tersebut didapat hasil perhitungan seperti yang terangkum pada tabel di bawah ini:

Tabel 10. Hasil Uji t Perbedaan Layanan Informasi

Paired Samples Statistics

\begin{tabular}{|rc|r|r|r|r|}
\hline & \multicolumn{1}{|c|}{ Mean } & N & \multicolumn{1}{c|}{ Std. Deviation } & \multicolumn{1}{|c|}{ Std. Error Mean } \\
\hline \multirow{2}{*}{ Pair 1 } & Pretest & 90.9143 & 35 & 24.97690 & 4.22187 \\
& Posttest & 136.1429 & 35 & 14.37756 & 2.43025 \\
\hline
\end{tabular}

Rata-rata sampel pre-eksperimen dan post-eksperimen: 90,9143 dan 136,1429. Standar Deviasi post informasi : 24,97690 dan 14,37756. $\mathrm{p}$ (value) $=0,00$. Hasil dari sign di atas menyatakan bahwa $0,00 \leq 0,05$ maka Ho ditolak dan Ha diterima. Hipotesa dari penelitian ini adalah:

$\mathrm{Ho}_{3}$ : Tidak terdapat pengaruh layanan informasi terhadap penyesuaian diri siswa di sekolah SMP Negeri 18 Batam

$\mathrm{Ha}_{3:}$ Terdapat pengaruh layanan informasi terhadap penyesuaian diri siswa di sekolah SMP Negeri 18 Batam. 
Karena $0,00 \leq 0,05$ maka kesimpulan yang didapat : Ha diterima (Terdapat pengaruh layanan informasi terhadap penyesuaian diri siswa di sekolah SMP Negeri 18 Batam).

\section{PEMBAHASAN}

\section{Penyesuaian Diri Sebelum Diberikan Layanan Informasi}

Penyesuaian diri merupakan salah satu hal yang perlu diperhatikan pada pribadi peserta didik, dengan penyesuaian diri bagus maka proses perkembangan anak tidak akan ada hambatan akan tetapi jika penyesuaian diri siswa buruk terhadap orang lain akan berakibat buruk pula bagi perkembangannya, sehingga siswa tidak mampu bergaul dengan teman dan lingkungannya sehingga perkembangan remajanya terhambat.

Sebagaimana dijelaskan oleh Muhammad Asrori, (2009:201-202) karakteristik penyesuaian diri remaja adalah pesatnya perkembangan fisik dan psikis, seringkali menyebabkan remaja mengalami krisis peran dan identitas. Sesungguhnya, remaja senantiasa berjuang agar dapat memainkan perannya sesuai dengan perkembangan masa peralihannya dari masa anak-anak menjadi dewasa. Tujuannya adalah memperoleh identitas diri yang semakin jelas dan dapat dimengerti serta diterima oleh lingkungannya, baik lingkungan keluarga, sekolah, ataupun masyarakat.

Kondisi penyesuaian diri siswa di SMP Negeri 18 Batam sebelum diberi layanan informasi dengan data yang sudah ada rata-rata siswa dalam kategori sangat rendah.Hanya beberapa siswa saja yang memiliki penyesuaian sedang dan tinggi. Oleh karena itu peneliti ingin merubah penyesuaian diri siswa ini karena penyesuaian diri siswa sangat penting dimiliki oleh setiap pribadi siswa untuk kelangsungan pergaulan dan pendidikannya.

\section{Penyesuaian Diri Siswa Setelah Diberikan Layanan Informasi}

Tujuan layanan informasi yakni menerima dan memahami informasi tertentu yang dapat digunakan oleh peserta didik untuk keperluan hidupnya sehari-hari dan perkembangan dirinya, membekali individu dengan berbagi pengetahuan dan pemahaman tentang berbagai hal yang berguna untuk mengenal diri, merencanakan, dan mengembangkan pola kehidupan sebagai pelajar. Post test dilakukan untuk mengetahui tingkat penyesuaian diri siswa setelah mendapat layanan informasi. pemberian layanan informasi yang direncanakan dalam lima kali layanan dengan alokasi 45 menit, setiap tatap muka. Pemberian layanan informasi diberikan dengan metode ceramah, diskusi dan tanya jawab kepada siswa, diantaranya sebagai berikut: Deskripsi proses pelaksanaan layanan dari pertemuan pertama sampai pertemuan 5 akan dijelaskan berikut ini: 


\section{a. Pertemuan Pertama}

Pertemuan pertama dilaksanakan di ruang kelas VIII pada pagi hari jumat, tanggal 12 Juni 2015. Pertemuan pertama peneliti memberikan materi dengan topik, pola hubungan yang baik dengan teman sebaya. Tujuan layananya adalah mampu menjalin hubungan sosial dengan teman sebaya sesuai peranya sebagai pria dan wanita.

b. Pertemuan Kedua

Pertemuan kedua dilaksanakan di ruang kelas VIII pada pagi hari sabtu, tanggal 13 Juni 2015.Pertemuan Kedua peneliti memberikan materi dengan topik tata krama sisiwa.Tujuan layanan yaitu siswa mampu memahami nilai dan cara-cara berperilaku yang sesuai dalam kehidupan diluar kelompok sebaya. Dengan uraian materi antara lain pengertian tata krama, tata karma dengan teman sebaya, tata krama pergaulan dengan guru, tata krama pergaulan dengan ibu dan bapak.

c. Pertemuan Ketiga

Pertemuan Ketiga dilaksanakan di ruang kelas VIII pada pagi hari senin, tanggal 15 Juni 2015. Pertemuan Ketiga pembimbing memberikan materi dengan topik pengendalian diri. Tujuan layanan ini adalah memberikan pemahaman kepada siswa tentang pengendalian diri dan perlunya mentaati norma dan peraturan yang berlaku. Uraian materi yang diberikan antara lain adalah pengertian pengendalian diri, contoh dan sikap pengendalian diri, dan manfaat penegendalian diri

d. Pertemuan Ke Empat

Pertemuan Keempat dilaksanakan di ruang kelas VIII pada pagi hari selasa, tanggal 16 Juni 2015. Pertemuan Keempat peneliti memberikan materi dengan topik cara mencari dan disenangi teman. Tujuan layanan ini adalah agar siswa mampu memahami cara mencari dan disenangi teman serta cara menolak ajakan negatif teman sebaya.

e. Pertemuan Kelima.

Pertemuan kelima dilaksanakan di ruang kelas VIII pada pagi hari rabu, tanggal 17 Juni 2015. pertemuan Kelima pembimbing memberikan materi dengan topik prilaku sopan santun dalam kehidupan. Tujuan layanan ini adalah agar siswa mampu memahami nilainilai dan cara bertingkah laku sosial dalam kehidupan di luar kelompok sebaya. Dengan uraian materi antara lain belajar dan berprilaku sopan santun yang meliputi senyum,sapa, salam, dan sopan santun, iman dan takwa.

Peneliti memberikan layanan informasi sebanyak 5 kali layanan hal ini dilakukan agar terjadi perubahan penyesuaian diri siswa di SMPN 18 Batam. Hal ini terbukti setelah 
layanan diberikan siswa di SMPN 18 Batam terdapat perubahan. dan diharapakan anak dapat mempertahankan perubahannya dalam keefektifan kehidupan sehari-harinya.

\section{Pengaruh Layanan Informasi terhadap Penyesuaian Diri Siswa}

Dari hasil penelitian yang telah dilakukan terdapat pengaruh layanan informasi terhadap penyesuaian diri siswa yang diberikan peneliti sebanyak 5 kali layanan. Perubahan yang terjadi pada kelas eksperimen ini sangat tinggi dengan banyaknya perubahan. Hal ini terbukti tidak ada lagi siswa yang memiliki penyesuaian diri rendah. semua siswa mengalami peningkatan penyesuaian diri sehingga dapat disimpulkan layanan informasi memiliki pengaruh yang sangat besar terhadap penyesuaian diri ini karena dilkaukan secara berturut-turut, dalam 5 kali pertemuan.

\section{Saran}

Berdasarkan hasil penelitian diketahui bahwa penyesuaian diri siswa di sekolah pada siswa kelas VIII SMP Negeri 18 Batam dapat meningkat setelah memperoleh layanan informasi, berkenaan dengan hal tersebut peneliti memberikan saran:

1. Dalam meningkatkan penyesuaian diri siswa dilingkungan sekolah seharusnya dapat juga menggunakan jenis layanan bimbingan konseling yang lain, misalnya layanan bimbingan kelompok.

2. Peningkatan penyesuaian diri dengan kategori sangat tinggi sebesar 3\% seharusnya dapat ditingkatkan lagi, sehingga penyesuaian diri siswa terhadap lingkungan sekolah lebih optimal.

Layanan informasi dapat meningkatkan penyesuaian diri terhadap lingkungan sekolah yang cukup signifikan, seharusnya dapat ditingkatkan lagi yang lebih signifikan dengan mengoptimalkan layanan informasi.

\section{DAFTAR PUSTAKA}

Muhammad Ali dan Muhammad Ansori. (2005). Psikologi Remaja Perkembangan Peserta Didik. Jakarta: Bumi Aksara.

Al-Mighwar. (2006). Psikologi Remaja. Bandung: Pustaka Setia.

Arikunto, Suharsimi. (2006). Prosedur Penelitian Suatu Pendekatan Praktik. Jakarta: Rineka Cipta.

Sofyan S, Willis. (1986). Problema Remaja dan Pemecahannya. Bandung: Angkasa.

Sugiyono. (2005). Statistika Untuk Penelitian. Bandung: Alfabeta

Sunarto dan Agung Hartono. (2002). Perkembangan Peserta Didik. Jakarta: Rineka Cipta. Gerungan. (2004). Psikologi Sosial. Bandung: Refika Aditama.

Sunarto dan Agung Hartono. (2002). Perkembangan Peserta Didik. Jakarta: Rineka Cipta. Sugiyono. (2013). Metodologi Penelitian Kualitatif dan Kuantitatif. Bandung: Alfabeta. Liche, Aries dan Bernadette. (2005). Psikologi Eksperimen. Jakarta: Penerbit PT. Indeks. 
Muhammad Ansori. (2009). Psikologi Pembelajaran. Bandung: CV. Wacana Prima.

Achmad, Juntika. (2006). Bimbingan \& Konseling Dalam Berbagai Latar Kehidupan. Bandung: PT. Refika Aditama.

Achmad, Juntika. (2005). Strategi Layanan Bimbingan dan Konseling. Bandung: PT. Refika Aditama. Achmad, Juntika. (2013). Dinamika Perkembangan Anak \& Remaja. Bandung: PT. Refika Aditama. Ki Fudyartanta. (2011). Psikologi Perkembangan. Yogyakarta: Pustaka Pelajar.

Sugiyono. (2013). Statistika Untuk Penelitian. Bandung: Alfabeta. 